\title{
Identifikasi Staphylococcus sciuri dan S. hominis pada Ikan Kerapu di Pasar Ikan Kedonganan dengan Analisis Sekuen 16S rRNA
}

\author{
(IDENTIFICATION OF STAPHYLOCOCCUS SCIURI AND S. HOMINIS \\ BACTERIA ON GROUPER (EPINEPHELUS SEXFASCIATUS) OF \\ THE KEDONGANAN FISH MARKET BASED ON 16S RRNA SEQUENCE ANALYSIS)
}

\author{
I Nengah Kerta Besung ${ }^{1 *}$, Ni Komang Eka Agustiani ${ }^{2}$, \\ I Gusti Ngurah Kade Mahardika ${ }^{3,4}$ \\ ${ }^{1}$ Laboratorium Mikrobiologi Veteriner, \\ Fakultas Kedokteran Hewan, Universitas Udayana \\ ${ }^{2}$ Praktisi Dokter Hewan di Kabupaten Badung, Bali \\ ${ }^{3}$ Laboratorium Virologi Veteriner, FKH Unud \\ ${ }^{4}$ International Biodiversity Research Center Unud \\ Jln Sudirman, Sanglah, Denpasar, Bali, Indonesia 80234 \\ Telpon: 0361 223791; *Email: kerta_besung@unud.ac.id
}

\begin{abstract}
Grouper are reef fish which can be cultivated because highly commercial value. There are many different types of bacteria in the digestive tract of grouper, one of them is Staphylococcus. Staphylococcus sp. is a Gram positive, non spora, non motile, and facultative anaerobic. Most of Staphylococcus sp. are pathogenic in human and animals. The purpose of this study was to identify the species Staphylococcus sp. on grouper sold at the Kedonganan fish market, Kuta District, Badung Regency, Bali Province based on 16S rRNA sequence analysis. This study used grouper feces as a samples from 20 fishes. Staphylococcus sp. from feces were cultured in media Blood Agar. Sequence analysis 16S rRNA Staphylococcus sp. was conducted with PCR and sequencing method. This study can identify the bacteria Staphylococcus sciuri and Staphylococcus hominis.
\end{abstract}

Keywords: grouper; Staphylococcus; PCR; 16S rRNA

\begin{abstract}
ABSTRAK
Ikan kerapu (Epinephelus sexfasciatus) adalah ikan karang yang dapat dibudidayakan karena nilai komersialnya tinggi. Dalam saluran pencernaan ikan kerapu ada banyak jenis bakteri, salah satunya adalah Staphylococcus sp. Staphylococcus sp. adalah bakteri Gram positif, tidak berspora, tidak motil, dan fakultatif anaerobik. Sebagian besar Staphylococcus sp. patogen pada manusia dan hewan. Tujuan dari penelitian ini adalah untuk mengidentifikasi spesies Staphylococcus sp. pada kerapu yang dijual di Pasar Ikan Kedonganan, Kecmatan Kuta, Kabupaten Badung Provinsi Bali berdasarkan analisis urutan 16S rRNA. Penelitian ini menggunakan feses ikan kerapu sebanyak 20 sampel. Sampel dikultur pada media agar darah. Analisis urutan 16S rRNA Staphylococcus sp. dilakukan dengan menggunakan PCR dan metode sequencing. Penelitian ini dapat mengidentifikasi bakteri Staphylococcus sciuri dan Staphylococcus hominis dari tinja ikan kerapu.
\end{abstract}

Kata kunci: kerapu; Staphylococcus; PCR; 16S rRNA 


\section{PENDAHULUAN}

Pasar Ikan Kedonganan merupakan pasar ikan yang terletak di Desa Kedonganan, Kecamatan Kuta, Kabupaten Badung, Bali. Ikan yang dijual di pasar tersebut, sebagian besar berasal dari hasil tangkapan nelayan setempat dan sekitarnya. Namun, ada juga yang merupakan kiriman dari kabupaten lain di wilayah Bali serta dari provinsi lain. Ikan kerapu (Epinephelus sexfasciatus) merupakan salah satu ikan yang dijual di Pasar Ikan Kedonganan. Ikan kerapu ini memiliki nilai komersial yang tinggi, daging yang tebal, lezat, dan berprotein tinggi, serta dapat dibudidayakan sebagai ikan hias (Mariskha dan Abdulgani, 2012). Daging yang tebal dengan kandungan protein yang tinggi menyebabkan kuman dapat tumbuh dan berkembang. Ikan kerapu mudah terinfeksi penyakit yang disebabkan oleh agen penyakit menular seperti virus, bakteri, jamur dan parasit (Ilmiah et al., 2013). Bakteri yang terdapat pada saluran pencernaan ikan kerapu ada sembilan spesies antara lain Lactococcus sp., Carnobacterium sp., Bacillus sp., Eubacterium sp., Pseudomonas sp., Lactobacillus sp., Micrococcus sp., Bifidobacterium sp., dan Staphylococcus sp (Purwandari dan Chen, 2013 ).

Bakteri Staphylococcus sp. termasuk bakteri Gram positif, tidak berspora, tidak motil, fakultatif anaerob, kemoorganotrofik, dan metabolisme fermentative (Vos et al., 2011). Sebagian besar bakteri Staphylococcus bersifat patogen pada manusia dan hewan (Bein et al., 2013) dan pernah dilaporkan menyebabkan wabah pada rumah sakit tersier di Benin (Ahoyo et al., 2013). Gotz et al. (2006) menyatakan bahwa saat ini terdapat 36 spesies Staphylococcus dan beberapa subspesiesnya. Adanya tingkat keragaman spesies yang tinggi pada genus Staphylococcus tersebut menunjukkan bahwa secara genetik tidak ada dua individu dalam satu spesies yang sama persis.

Teknik identifikasi bakteri dengan metode analisis molekuler merupakan teknik identifikasi modern yang dapat meminimalisir kelemahan dari teknik identifikasi secara konvensional. Polymerase Chain Reaction (PCR) merupakan metode enzimatis untuk melipatgandakan sekuen nukleotida tertentu secara eksponensial dengan cara in vitro. Teknik ini telah berhasil mengidentifikasi mikroorganisme dari lingkungan secara spesifik. Salah satu teknik identifikasi analisis molekuler yaitu analisis sekuens 16S rRNA. Analisis sekuens 16S rRNA merupakan analisis sederhana yang umumnya digunakan untuk mengidentifikasi mikroorganisme (Bavykin et al., 2004). Tujuan dari penelitian ini adalah untuk mengidentifikasi spesies Staphylococcus sp. pada ikan kerapu yang dijual di Pasar Ikan Kedonganan berdasarkan analisis urutan 16S rRNA.

\section{METODE PENELITIAN}

Sebanyak 20 ekor ikan kerapu digunakan sebagai sampel penelitian. Sampel diambil dari Pasar Ikan Kedonganan dengan empat kali pengambilan. Feses ikan kerapu diambil dengan cara memijat bagian abdomen ikan kerapu sampai feses keluar dari anus dan ikan juga dibedah pada bagian perut untuk memotong bagian usus yang berisi feses.

Isolasi Kuman. Isolasi dan identifikasi kuman dilakukan di Laboratorium Bakteriologi, Fakultas Kedokteran Hewan, Universitas Udayana. Sampel feses kemudian ditanam pada media biakan agar darah untuk memperoleh isolat bakteri Staphylococcus sp. Koloni yang tumbuh diwarnai dengan pewarna Gram. Bakteri yang berbentuk bulat bergerombol seperti buah anggur dan Gram positif dicurigai sebagai kuman Staphylococcus sp. Bakteri Staphylococcus sp. kemudian diidentifikasi dengan metode Polymerase Chain Reaction (PCR).

Polymerase Chain Reaction (PCR). Ekstraksi DNA kuman dan uji PCR dilakukan di Laboratorium Biomedik FKH Unud. Tahapan PCR meliputi ekstraksi DNA, amplifikasi DNA dan elektroforesis. Ekstraksi DNA bakteri dilakukan dengan cara mengambil satu koloni Staphylococcus sp dengan ose dan dimasukkan ke dalam tabung Eppendorf yang sudah berisi $250 \mu \mathrm{L}$ chelex $10 \%$. Selanjutnya tabung dipusing selama satu menit, diputar dengan kecepatan $15.000 \mathrm{rpm}$ selama 30 detik menggunakan microcentrifuge, dan diinkubasikan selama 45 menit pada suhu $95^{\circ} \mathrm{C}$ menggunakan heating block. Setelah selesai, tabung dipusing kembali selama satu menit, dan diputar selama 30 detik.

Amplifikasi DNA bakteri menggunakan primer 16S rRNA TStaG422 (5'-GGC CGT GTT GAA CGT GGT CAA ATC A-3') dan TStag765 (5'-TIA CCA TTT CAG TAC CTT CTG GTA A3') (Martineau et al., 2001). Dibuat PCR mixes sejumlah $24 \mu \mathrm{L}$ yang terdiri dari $14,5 \mu \mathrm{L}$ ddH2O, $2,5 \mu \mathrm{L}$ 10X PCR Buffer (Hot start), 2,5 $\mu \mathrm{L}$ dNTPs 
(8 mM), 2,0 $\mu \mathrm{L}$ MgCl2 Solution (25 mM), 1,25 $\mu \mathrm{L}$ dari masing-masing primer $(10 \mu \mathrm{M}), 0,125$ $\mu \mathrm{L}$ Amplitaq Hot start (5 units/ $\mu \mathrm{L})$, dan $3 \mu \mathrm{L}$ DNA template. Amplifikasi menggunakan alat Thermal Cycler (Applied Biosystem). Tahapan Pre-PCR selama 10 menit pada suhu $94^{\circ} \mathrm{C}$. Proses PCR dilakukan sebanyak 38 siklus dengan tahap denaturasi 30 detik suhu $94^{\circ} \mathrm{C}$, annealing 30 detik suhu $50^{\circ} \mathrm{C}$, extention selama 45 detik suhu $72^{\circ} \mathrm{C}$. Post PCR 10 menit suhu $72^{\circ} \mathrm{C}$ dan satu menit suhu $24^{\circ} \mathrm{C}$.

Sebanyak $4 \mu \mathrm{L}$ dari volume produk ditambahkan dengan $1 \mu \mathrm{L}$ loading dye (Bromphenol-blue dan Cyline Cyanol) dan selanjutnya dielektroforesis pada gel $1 \%$ yang telah diisi etidium bromide ( $\mathrm{EtBr})$ sebanyak 4 $\mu \mathrm{L}$. Elektroforesis dilakukan pada tegangan 100 $\mathrm{v}$, dengan arus $400 \mathrm{~mA}$ menggunakan marker 100 bp DNA ladder (Invitrogen) selama 30 menit. Visualisasi fragmen DNA dilakukan di bawah sinar ultraviolet dan foto diambil menggunakan kamera digital

Hasil PCR selanjutnya disekuensing di Universitas Barkley USA untuk memperoleh urutan DNA masing-masing isolat. Metode yang digunakan adalah Automatic Sanger / BigDye Terminator sekuensing (Sambrook dan Russel, 2001). Data sekuens diedit menggunakan Clustal $W$ dalam program MEGA 5. Hasil runutan kemudian di-BLAST untuk mendapatkan sekuens data dan dibandingkan dengan kuman Staphylococcus sp yang terdapat di GenBank dan disusun pohon filogenetiknya. Pohon filogenetik disimpulkan dengan menggunakan metode Neighbor-Joining. Persentase pohon filogenetik digunakan untuk menentukan taksa yang sama dengan cara dites bootstrap (100 ulangan) yang ditampilkan di samping cabang. Jarak evolusi dihitung dengan menggunakan metode Kimura 2-parameter dan analisis Evolusioner dilakukan di MEGA 5 (Tamura et al., 2011).

\section{HASIL DAN PEMBAHASAN}

Hasil isolasi pada media agar darah terlihat koloni berukuran sedang sampai besar, berwarna kuning halus, dan menunjukkan hemolisis. Setelah dilakukan pewarnaan Gram terlihat bahwa bakteri berbentuk coccus, Gram positif bergerombol seperti buah anggur. Isolat bakteri tersebut selanjutnya diambil untuk diekstraksi DNA dan amplifikasi 16S rRNA. Amplifikasi fragmen 16S rRNA menggunakan primer TStaG422 dan TStag765 (Martineau et al., 2001). Elektroforesis hasil PCR pada agarose $1 \%$ disajikan pada Gambar 1. Sebanyak tujuh isolat dari 20 sampel dicurigai sebagai Staphylococcus sp dan hanya empat sampel yang dapat diamplifikasi.

Produk DNA dari empat bakteri Staphylococcus selanjutnya disekuensing dan hasil yang didapat diedit dengan mengunakan program MEGA 5 (Tamura et al., 2011). Hasil perunutan data sekuen yang dapat dibaca dengan baik adalah berkisar 269 hingga 307 bp. Urutan DNA yang telah diedit selanjutnya dibandingkan dengan data yang ada di GenBank dengan menggunakan fasilitas BLAST untuk konfirmasi spesies. Hasil yang didapat disajikan pada Tabel 1.

Pada Tabel 1 ditunjukkan bahwa dua dari empat hasil sekuensing yang didapat memiliki kekerabatan dengan bakteri Staphylococcus sp. yaitu KD.B.05 dan KD.C.01. Sampel KD.A.05 teridentifikasi sebagai Enterococcus aquamarines dengan homologi $99 \%$ setelah dibandingkan dengan sekuens yang diperoleh di GenBank. Sampel bakteri dari ikan dengan kode KD.D.01 tidak dapat dikonfirmasi karena homologi hanya $88 \%$ dengan Staphylococcus closii dan Enterococcus faecalis.

Jarak genetik yang ditunjukkan dari dua sampel bakteri Staphylococus sp. dan dua data dari Genbank bervariatif. Analisis jarak genetik pada setiap spesies yang sudah terindentifikasi disajikan pada Tabel 2 .

Pada Tabel 2 ditunjukkan bahwa isolat KD.B.05 adalah Staphylococcus sciuri ( $S$. sciuri) dan isolat KD.C.01 adalah Staphylococcus hominis (S. hominis). Untuk menentukan hubungan bakteri Staphylococcus pada ikan kerapu di Pasar Ikan Kedonganan dengan bakteri Staphylococcus yang ada di dunia, dibutuhkan penambahan data yang diunduh dari GenBank. Data berupa sekuens yang sudah diunduh dari GenBank di-alignment dengan sampel yang dikelompokkan dalam satu spesies. Hasil analisis pohon asal usul setiap kelompok spesies yang di-alignment dengan data dari GenBank disajikan pada Gambar 2 dan Gambar 3. Analisis tersebut menunjukkan bahwa isolat KD.B.05 adalah $S$. sciuri dan isolat KD.C.01 adalah $S$. hominis.

Analisis sekuens 16S rRNA merupakan analisis sederhana yang umumnya digunakan untuk mengidentifikasi mikroorganisme (Bavykin et al., 2004). Urutan gen 16S rRNA memungkinkan diferensiasi antara organisme pada tingkat genus semua filum utama bakteri, 
serta mengklasifikasikan strain pada tingkat spesies dan subspesies. Analisis sekuens 16S rRNA pada penelitian ini telah berhasil dilakukan dengan maksimal. Data hasil sekuensing yang didapat kemudian diedit dan dianalisis dengan menggunakan program MEGA 5 (Tamura et al., 2011). Analisis MEGA 5 memberikan hasil dari empat sampel bakteri pada ikan kerapu yang ada, hanya dua sampel merupakan bakteri Staphylococcus. Sampel KD.B.05 teridentifikasi sebagai Staphylococcus sciuri (S. sciuri) dan KD.C.01 teridentifikasi sebagai Staphylococcus hominis (S. hominis). Bakteri $S$. sciuri merupakan bakteri kokus Gram positif, oksidase-positif, anggota koagulasenegatif dari genus bakteri Staphylococcus. Bakteri S. sciuri dapat dibedakan dari semua Staphylococcus lain atas dasar morfologi koloni,

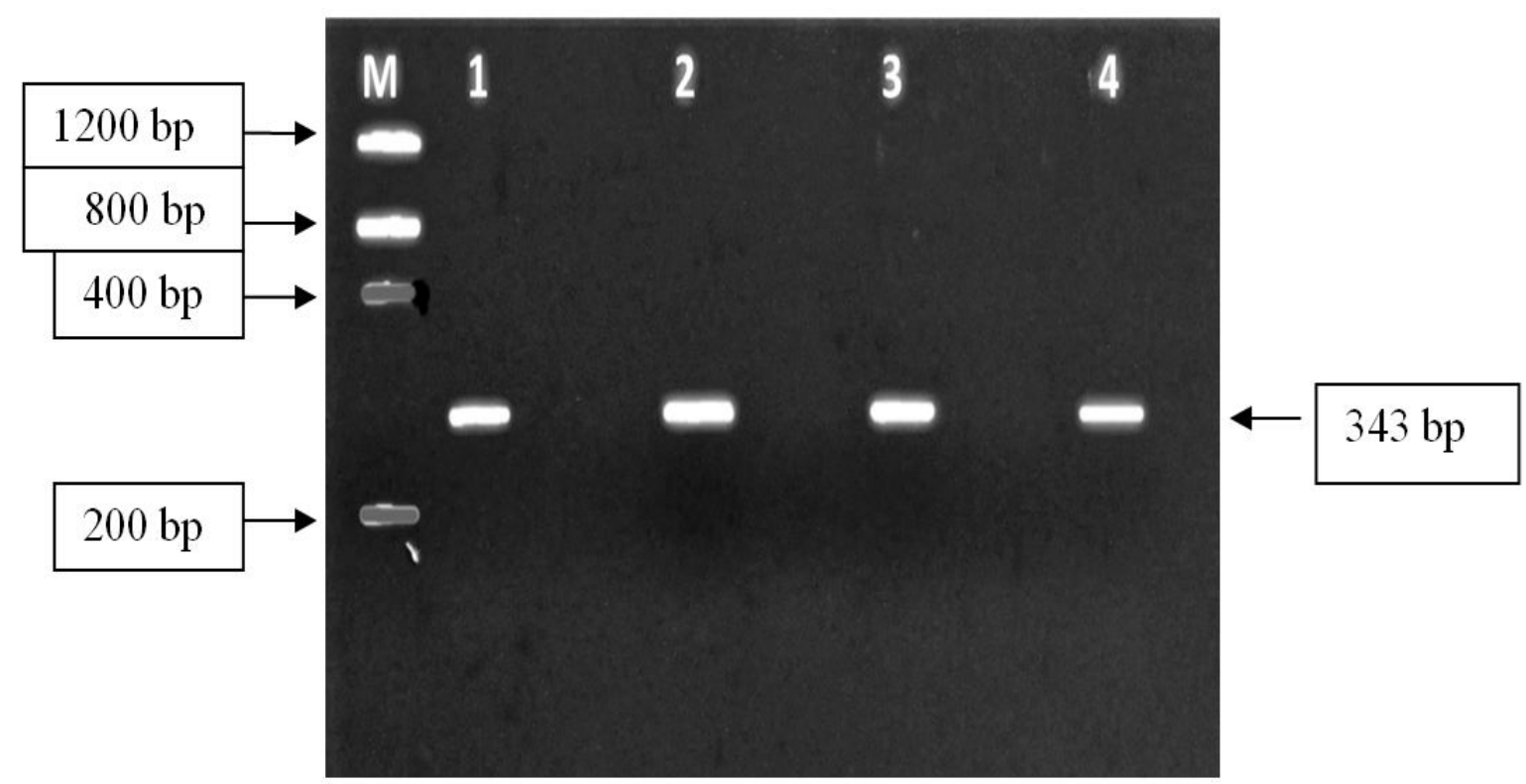

Gambar 1. Elektroforesis hasil Polymerase Chain Reaction (PCR) pada agarose 1\%. M adalah Marker, 1 isolat KD.A.05, 2 isolat KD.B.05, 3 isolat KD.C.01, 4 isolat KD.D.01.

Tabel 1. Hasil BLAST bakteri Staphylococcus sp yang berasal dari feses ikan kerapu di Pasar Ikan Kedonganan, Kecamatan Kuta, Kabupaten Badung Provinsi Bali

\begin{tabular}{cclc}
\hline No & Kode sampel & \multicolumn{1}{c}{ GenBank } & Kedekatan \\
\hline 1 & KD.A.04 & - & - \\
2 & KD.A.05 & Enterococcus aquimarines & $99 \%$ \\
3 & KD.B.01 & - & - \\
4 & KD.B.05 & Staphylococcus sciuri & $100 \%$ \\
5 & KD.C.01 & Staphylococcus hominis & $99 \%$ \\
6 & KD.C.04 & - & - \\
7 & KD.D.01 & Staphylococcus kloosii & $88 \%$ \\
& & Enterococcus faecalis & $88 \%$ \\
\hline
\end{tabular}

Tabel 2. Jarak genetik sampel bakteri Staphylococcus yang ditemukan dengan data dari Genbank

\begin{tabular}{lllll}
\hline \multicolumn{1}{c}{ KODE } & KD.B.05 & KD.C.01 & Staphylococcus sciuri & Staphylococcus hominis \\
\hline KD.B.05 & & & & \\
KD.C.01 & 0.102 & & & \\
Staphylococcus sciuri & 0.004 & 0.106 & & \\
Staphylococcus hominis & 0.098 & 0.011 & 0.102 & \\
\hline
\end{tabular}




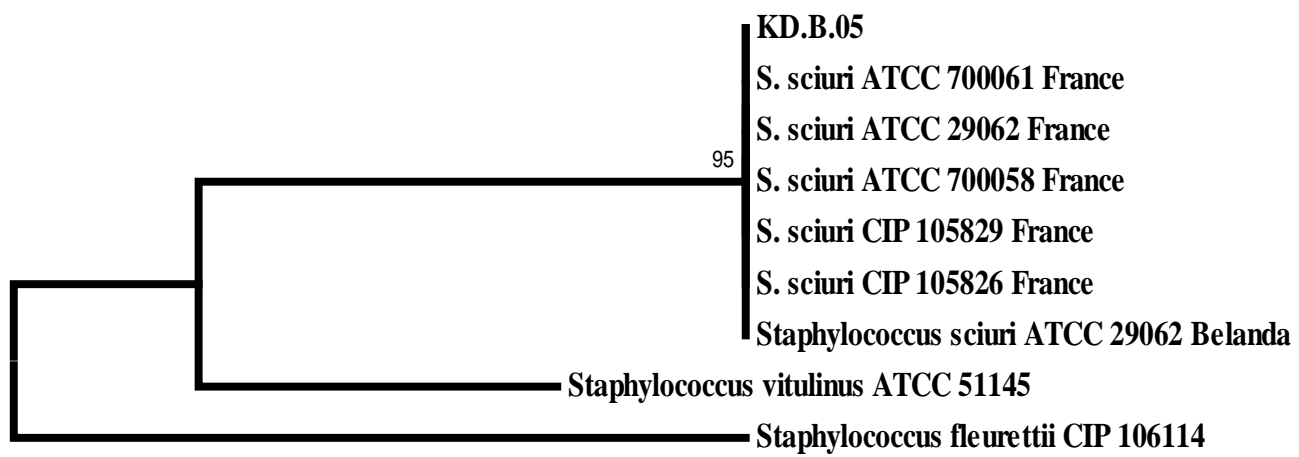

†.002

Gambar 2. Pohon filogeni Staphylococcus sciuri dari sampel KD.B.05 dengan data dari

GenBank. Staphylococcus vitulinus dan Staphylococcus fleurettii digunakan sebagai outgroup.

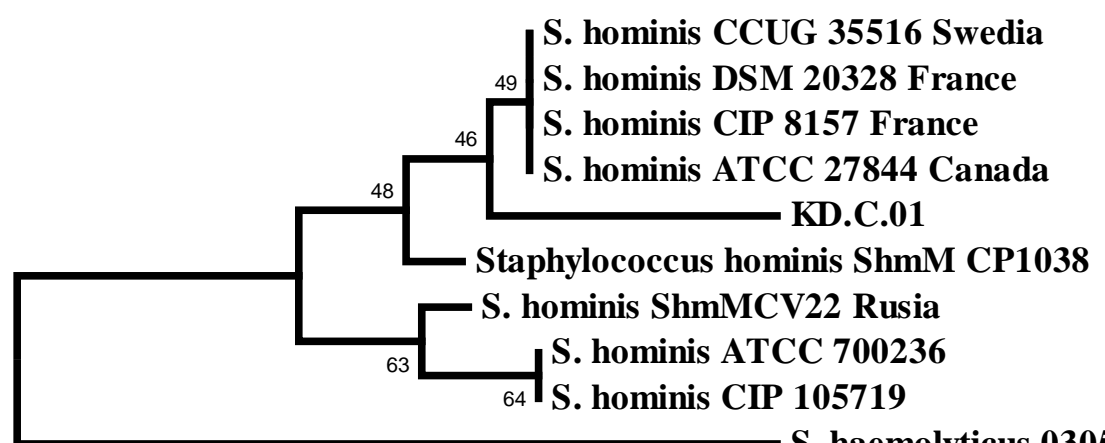

S. haemolyticus 030515-259-1853.2

Gambar 2. Pohon filogeni Staphylococcu hominis dari sampel KD.C.01 dengan data dari GenBank. Staphylococcus haemolyticus digunakan sebagai outgroup.

dinding sel peptidoglikan, produksi asam dari selobiosa, dan biasanya dari fucose dalam kondisi aerobik, dan kombinasi karakteristik lainnya (Nurhidayu et al., 2012). Bakteri S. sciuri merupakan bakteri patogen penting pada manusia yang bertanggung jawab terhadap beberapa gangguan penyakit (Ahoyo et al., 2013), seperti infeksi luka (Coimbra et al., 2011), peritonitis, syok septik, dan penyakit radang panggul (Stanley et al., 2013). Beberapa strain patogen dari $S$. sciuri dapat menyebabkan mastitis pada ternak ruminansia seperti kambing dan sapi. Selain itu S. sciuri dapat menyebabkan epidermitis eksudatif (EE) pada babi dan tikus, dengan demikian dapat dikatakan bahwa bakteri ini merupakan agen zoonosis (Cervinkova et al., 2013). Penelitian lainnya, amplifikasi DNA pada bandeng kering dengan menggunakan analisis sekuen 16S rDNA ditemukan bakteri $S$. sciuri subsp. sciuri (Coimbra et al., 2011).

Bakteri $S$. hominis adalah anggota spesies koagulase negatif dari genus Staphylococcus. Bakteri ini dapat dibedakan dari Staphylococcus lainnya terutama atas dasar kombinasi morfologi koloni dan pola pigmen, tidak ada pertumbuhan terdeteksi dalam thioglycolate, toleransi terhadap $\mathrm{NaCl}$ rendah, dan pola reaksi karbohidrat juga berbeda (Park et al., 2011). Bakteri S. hominis dapat menyebabkan infeksi arteri karotis dengan embolisasi septik (Dansey et al., 2015). Bakteri $S$. hominis biasanya tidak menyebabkan penyakit pada manusia, tetapi akhir-akhir ini diakui sebagai bakteri yang berpotensi patogen dan kadang-kadang bersifat oportunistik dan nosokomial serta menyebabkan infeksi pada pasien dengan sistem imun lemah. Bakteri ini 
dilaporkan berpotensi menyebabkan infeksi yang mengancam manusia, seperti endokarditis infektif (Jiang et al., 2012). Joshi et al. (2011) menemukan $S$. hominis pada ikan tuna sebagai penghasil histamin yang tinggi. Hardi et al. (2018) menemukan bakteri Staphylococcus sp pada feses ikan nila dan ikan lele.

Selain bakteri $S$. sciuri dan S. hominis, pada penelitian ini juga ditemukan bakteri Enterococcus aquamarines, sedangkan satu isolat yang lain belum dapat ditentukan sebagai Enterococcus sp. atau Staphylococcus sp. Penelitian ini juga membuktikan bahwa berbagai koloni dan hasil pewarnaan Gram bakteri bisa mempunyai homologi yang mirip dan analisis sekuens 16SrRNA dapat membantu identifikasi bakteri, terutama antara Staphylococcus dan Enterococcus. Satu isolat tampaknya bakteri baru yang belum pernah diidentifikasi sebelumnya dan data genetiknya tidak tersedia di GenBank. Kajian lebih lanjut diperlukan untuk mengidentifikasi bakteri tersebut untuk dapat dideklarasikan sebagai spesies baru.

\section{SIMPULAN}

Berdasarkan hasil penelitian dapat disimpulkan bakteri Staphylococcus dapat diidentifikasi dari feses ikan kerapu yang dijual di Pasar Ikan Kedonganan yaitu Staphylococcus sciuri dan Staphylococcus hominis.

\section{SARAN}

Peran Staphylococcus sciuri dan Staphylococcus hominis pada manusia, ternak dan ikan kerapu perlu dikaji lebih lanjut. Ditemukannya bakteri pada ikan yang dijual, maka para penjual ikan harus meningkatkan sanitasi dan penyimpanan ikan.

\section{UCAPAN TERIMA KASIH}

Terima kasih penulis ucapkan atas pendanaan yang diberikan oleh USAID melalui sub-grant dari NAS (National Academy of Science) dengan NAS sub-grant number PGA2000001987 dan sponsor grant award number AID-OAA-A-11-00012 dengan judul Building Indonesia Capacity through Genetic Assessment of Commercial Fish Species. Ucapan terimakasih juga ditujukan kepada Dekan Fakultas Kedokteran Hewan, Universitas
Udayana, yang telah memberikan segala fasilitas sehingga penelitian ini dapat berjalan dengan baik.

\section{DAFTAR PUSTAKA}

Ahoyo TA, Pazou YE, Baba-Moussa L, Gbohou A , Boco M , Dramane KL, Aminou T. 2013. Staphylococcus sciuri outbreak at Tertiary Hospital in Benin. J Med Microb Diagn 2: 3

Bavykin SG, Lysov YP, Zakhariev V, Kelly JJ, Jackman J, Stahl DA, Alexey C. 2004. Use of $16 \mathrm{~S}$ rRNA, 23S rRNA, and gyrB Gene Sequence Analysis To Determine Phylogenetic Relationships of Bacillus cereus Group Microorganisms. Journal of Clinical Microbiologi 42(8): 3711-3730.

Cervinkova D, Vlkova H, Borodacova I, Makovcova J, Babak V, Lorencova A, Vrtkova I, Marosevic D, Jaglic Z. 2013. Prevalence of mastitis pathogens in milk from clinically healthy cows. Veterinarni Medicina 58(11): 567-575

Coimbra DG, Alda GCS. Almeida, Jorge BO,. Júnior, da Silva LA, Pimentel BJ, Daniel LG, Luciana GS, Moreira, Eurípedes A, Silva-Filho, Tiago G, de Andrade. 2011. Wound infection by multiresistant Staphylococcus sciuri identified by molecular method. New Microbiologica 34: 425-427

Dansey K, Stratton L, Brian D, Park MD. 2015. Staphylococcus hominis carotid artery infection with septic embolization . Journal of Vascular Surgery Cases 1(2): 81-83

Gotz F, Bannerman T, Schleifer KH. 2006. The Genera Staphylococcus and Macrococcus. Prokaryotes. Journal of Clinical Microbiologi 4: 5-75.

Hardi EH, Nugroho RA, Saptiani G, Sarinah R, Agriandini M, Mawardi M. 2018. Identification of potentially pathogenic bacteria from tilapia (Oreochromis niloticus) and channel catfish (Clarias batrachus) culture in Samarinda, East Kalimantan, Indonesia. Biodiversitas 19(2): 480-488.

Ilmiah, Jusoff K, Sukenda, Widanarni, Rustam. 2013. The Role of Probiotic Bacteria on Controlling Vibriosis in Tiger Grouper Fry (Epinephelus foscoguttatus). World Journal of Fish and Marine Sciences 5(6): 622-627. 
Jiang S, Zheng B, Ding W, Longxian L, Ji J, Zhang H, Xiao Y, Li L. 2012. WholeGenome Sequence of Staphylococcus hominis, an Opportunistic Pathogen. Journal of Bacteriology 194(17): 47614762.

Joshi PA, Vishal S, Bhoir. 2011. Study of Histamine Forming Bacteria in Commercial fish samples of Kalyan city. International Journal of Current Scientific Research 1(2): 39-42.

Mariskha PR, Abdulgani N. 2012. Aspek Reproduksi Ikan Kerapu Macan (Epinephelus sexfasciatus) di Perairan Glondonggede Tuban. Jurnal Sains dan Seni ITS 1(1): 27-31.

Martineau F, Picard FJ, Ke D, Paradis S, Roy PH, Ouellette M, Bergeron MG. 2001. Development of a PCR Assay for Identification of Staphylococci at Genus and Species Levels. Journal of Clinical Microbiology 39(7): 2541-2547.

Nurhidayu A, Ina-Salwany MY, Daud HM, Harmin SA. 2012. Isolation, screening and characterization of potential probiotics from farmed tiger grouper (Epinephelus fuscoguttatus). African Journal of Microbiology Research 6(9): 1924-1933.

Purwandari AR, Chen HY. 2013. Effects of Probiotic Bacillus subtilis on Intestinal Microbial Diversity and Immunity of Orange Spotted Grouper Epinephelus coioides. Journal of Applied Biotechnology 1(1): 25-36.
Park JY, Fox LK, Seo KS, McGuire MA, Park YH, Rurangirwa FR, Sischo WM, Bohach GA. Comparison of phenotypic and genotypic methods for the species identification of coagulase-negative staphylococcal isolates from bovine intramammary infections. Veterinary Microbiology 147(1): 142-148

Sambrook J, Russell DW. 2001. Molecular Cloning. A Laboratory Manual. $3^{\text {rd }}$ ed., Cold Spring Harbor Laboratory Press.

Stanley CN, Ugboma HAA, Ibezim EC, Attama AA. 2013. Prevalence and Antibiotic Susceptibility of Staphylococcus aureus and Other Staphylococcal Infections in Pregnant Women Attending Antenatal Clinic in a Tertiary Hospital in Port Harcourt, Nigeria. Infectious Diseases \& Therapy 2: 1-6

Tamura K, Peterson D, Peterson N, Stecher G, Nei M, Kumar S. 2011. MEGA 5.05: Molecular evolutionary genetics analysis using maximum likelihood, evolution distance, and maximum parsimony methode. Mol Biol Evol 10: 2731-2739.

Vos P, Garrity G, Jones D, Krieg NR, Ludwig W, Rainey FA, Schleifer K, Wiliam WB. 2011. Bergey's Manual of Systematic Bacteriology. $2^{\text {nd }}$ ed., Springer Science \& Business Media. 